〔藤化 第 43 巻，第 1 号，p. $28 \sim 36 ， 1969$ ]

\title{
新アミン誘導体の化学構造とその植物生理活性について
}

\author{
白川憲夫, 竹内正毅, 村上 泰, 富樫邦彦 \\ (中外製奖株式会社綜合研究所)
}

昭和 43 年 6 月 10 日受理

\section{Relationship between Chemical Structure of New Amine Derivatives and Plant Physiological Activity}

By Norio ShIRAKawa, Masaki TakeUChI, Yasushi MURAKamI and Kunihiko Togash! Research Laboratory, Chügai Pharmaceutical Co., Ltd., Toshima-ku, Tokyo

This study was conducted to obtain some informations on the relationship between chemical structures of some new types of amine derivative such as $\mathrm{N}$-haloalkyl-benzylamine, N-alkyl-benzylamine, N-phenoxyalkyl-2-halogenopropylamine and N-phenylthioalkyl-2-halogenopropylamine and their plant physiological activities.

(1) In these amine derivatives, $\mathrm{HCl}$ salts of $\mathrm{N}$-phenoxyalkyl-2-halogenopropylamine derivatives showed the highest activity for the tested plants. They were found to be more effective when they had one chlorine in the 4 position of benzene ring and the number of methylene group linked to 2-chloropropylamine was 2,5 or 6 .

(2) The chlorosis activity specific to these compounds was the most remarkable when they had both of phenyl and 2-halogenopropylamine groups in their structure.

(3) Atom linked to benzene ring had important influence on activity. Descending order of activity was as follows: $0>C>S$.

(4) These compounds had lower acute toxicity to fish than sodium pentachlorophenoxide and lower mobility in soil.

(5) These compounds were much stable to ultraviolet rays.

(Received June 10, 1968)

\section{粕}

N-ハロアルキルーベンジルアミン，あるいは N-アル キルーベンジルアミン誘導体の作用性については，抗ア ドレナリン作用のあることが知られている(1).

筆者らは，これらの関連化合物拣たはその酸塩類が植 物に対し特徵ある生理作用を示すことから，その化学構 造と生理活性を比輘検討してきたところ, N-フェノキシ アルキルー2ーヒドロキシプロピルアミン誘導体，または その塩をハロゲン化用でハロゲン化することにより，き わめて特異的に活性の高まることを認めた。

本化合物の一般的な物理化学的性貿は, 水に不溶で, アルコール，アセトン、ペンビン，キシロールなどに難 溶であり，その八ロゲン化水素酸塩は水，アルコール， フセトンなどに可溶, ペンゼン，キシロールなどに不溶 である、またピクりン酸塩はアルコール，ベンゼン， ア
セトンなどに難溶で氷に不溶である。

一方, 本化合物の作用特性の1つを示す特異的な現象 としては，クロロシス（白化）作用にともなら植物茥葉 部の枯死過程があり, その症状は ATA (3-amino-1,2,4triazole) ${ }^{(2)}$ に類似している。このよ5な作用は茥葉部処 理で顕著であるが，土壤に処理した場合でも徐々に地上 部まで移行し，植物体をクロロシス化，枯死させる作用 が認められる。

筆者らは，このよ5な特徵ある新アミン化合物誘導体 の化学構造と植物生理活性について若千の検討をこころ みたが、ここにこれまで得られた結果を報告する。

なお本化合物の魚毒性, 紫外楾に対する安定性和よび 土镶䔟動性についても検討を行なったので，あるせて報 告したい. 


\section{実 験 方 法}

1. 供試薬鼡およびその合成法

1)<smiles>[R17]N([R17])Cc1[X]cccc1</smiles>

一級または二級のアルコールアミンとトルエンとを混 合しここれ $1 / 3$ モルの置換基を有する，または有しな いベンジルハライドを滴下し， $120^{\circ} \mathrm{C} て ゙ 4 〜 5$ 時間摫拌 する．終了後反応生成物をク口ロホルム層に移し，チオ ニルハライドでハロゲン化する.

2)

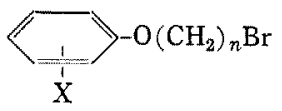

置換基を有する，または有しないフェール1モルと 1.5 モルのアルキレンジブロマイドとを混合し，これを 105 110 $\mathrm{C}$ に加熱鲵䢁しながらフェノールと同モルの 苛性ソーダ水溶液を滴下する. 滴下終了後 5 時間加熱描 拌し油層を減王蒸留してフェノキシ (置換) アルキレン ブロマイドを得る。

3)

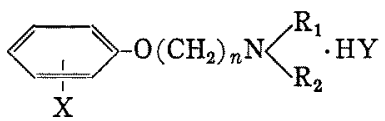

1)の合成法で, ベンジルハライドの代わりにフェノキ シ（㯰換）アルキレンブロマイドを滴下することにより 目的の化合物を得る。

4)<smiles>[Y]c1cccc(SCCN([R17])[R17])c1</smiles>

1)の合成法でペンジルハライドの代わりにフェニール チオ（置換）アルキレンブロマイドを滴下することによ り目的の化合物を得る。

1) 4)の化合物中 $X, R_{1}, R_{2}, Y, n$ については後記奏 験結果第 $1 \sim 4$ 表に示してある. また本文中に示されて いる新アミン誘導体のうち, 特徴ある植物生理活性を認 めた物啠については，その代表化合物の融点，分析値を 第 10 表にあとめてある.

\section{2. 供試薬剒の活性度測定方法}

1）殺草力： 供試した植物はキュウリ（品種：とき わ)、リョクトウ(緑豆), 栽培ヒ土およびメヒシバで温 室内にて内径 $10 \mathrm{~cm}$ のスヤキ鉢に播種し, 草丈 $5 \sim 10$ $\mathrm{cm}$ まで管理育成した，これに各薬郕の水溶液または界 面活性郕（ノニポール120）を添加し，乳郕とした薬液 を $1000 \mathrm{ppmw}$ の濃度で均一に茎葉部に散布し, 温室内
にて管理した，調査は薬剤処理後，作用発現症状の観察 をつつけ，20日目に地上部の植物体を切りとり，その生 体重量を湘定した。

2）クロロシス作用の測定： 供試植物は前述の植物 のほかコマッナ（品種：福葉）を加えた。方法は径 $9 \mathrm{~cm}$ のガラスシャーレに滤紙を敷き，所定濰度の薬液を 20 $\mathrm{ml}$ 加兄検定植物種子を入れたのちガラス恒温器（平均 $\left.25^{\circ} \mathrm{C}\right)$ にて 7 日間発茅生育させた。クロロシス作用は肉 眼で観察した。

3）魚毒性の険定方法：所定嵈度の薬液を 151 容 $\left(19 \times 39 \times 25 \mathrm{~cm}^{3}\right)$ のガラス水槽に 101 入れ，これにヒ メダカを 10 尾ずつ入れ，経時的に死魚の数を数えてゆ きTLm 值を求めた ${ }^{(3)}$ 。な和対照薬剷としては sodium pentachlorophenoxide t使用した。

4）紫外線に対する安定性検定方法：内径 $9 \mathrm{~cm} の$ ガラスシャーレに所定漕度の薬液を $20 \mathrm{ml}$ 入れ，殺菌 ンプ（東芝 GL-15，30 W) を高さ $30 \mathrm{~cm}$ のとこから 24 時間照射 ${ }^{(4)}$ 後，直ちに発芽試験を行ない結果を調べ た。

5）土壤中での移動性検定方法： 荒井らの方法によ る土壤移動程度測定装置 ${ }^{(5)}$ とより検討した。

\section{実 験 結 果}

\section{Nーハロアルキルーベンジルアミン誘導体の化学構} 造と植物生理活性

実験結果は第 1 表に示した。

第1表の結果から明らかなように本系統のアミン誘導 体は，Xがハロダン基またはニト口基の場合に強力な活 性を示すのを認めた。すなおり，1）Xが1個で $\mathrm{R}_{1}$ が水 素， $\mathrm{R}_{2}$ が 2-ハロゲンプロピル基の場合ではXが 4-クロ 口，4-ニト口基置換の化合物はいずれの植物に対しても 顕著な活性を示し，植物体はクロロシス化後枯死した またXが3ークロロ，3-フッソ，4-フッソ基のものはキュ ウリ、リョクトウに対しかなりの活性を示した．2）X が 2 個で $\mathrm{R}_{1}$ が水素， $\mathrm{R}_{2}$ が 2-ハロゲンプロピル基の場 合，Xが 2,4-ジクロロ，3,4-ジクロロ基の化合物では， いずれの植物に対しても全く活性を示さなかったが，X が 3,4-ジクロ口基で $\mathrm{R}_{1}$ がエチル基， $\mathrm{R}_{2}$ が $\mathrm{CH}_{2} \mathrm{CH}_{2} \mathrm{Cl}$ の構造のbのではキュウリ，リョクトウに対して高い活 性を認めた。.3）Xがメチル基，もしくは2-クロ口基の 場合は著しく活性が低い，4）ベンゼン核に置換基がな く $\mathrm{R}_{1}$ が水素, $\mathrm{R}_{2}$ が $\mathrm{CH}_{2} \mathrm{CH}_{2} \mathrm{Cl}$ でリョクトウのみに 対乙強力な活性作用を琶めた。 5) その他の化合物では 
第1老 Nーハロアルキルーベンシルアミン誘莩体の化学 棈造と植物生理活性

\begin{tabular}{|c|c|c|c|c|c|c|c|}
\hline \multirow{2}{*}{ 番 } & \multirow[b]{2}{*}{$X$} & \multirow[b]{2}{*}{$\mathrm{R}_{1}$} & \multirow[b]{2}{*}{$\mathrm{R}_{2}$} & \multirow[b]{2}{*}{$\mathrm{Y}$} & \multicolumn{3}{|c|}{ 活性度（指数） } \\
\hline & & & & & $\begin{array}{l}\neq \\
\dot{y}\end{array}$ & $\begin{array}{l}\text { 当ク } \\
\text { トウ }\end{array}$ & $t x$ \\
\hline$*$ & $\mathrm{PCP}-\mathrm{Na}$ & - & - & - & 5 & 5 & 4 \\
\hline$*$ & ATA & - & - & - & 5 & 5 & 4 \\
\hline 1 & 一 & $\mathrm{H}$ & $\stackrel{\mathrm{Cl}}{\mathrm{CH}_{2} \mathrm{CHCH}_{3}}$ & $\mathrm{Cl}$ & 0 & 0 & 0 \\
\hline 2 & $2-\mathrm{Cl}$ & $\mathrm{H}$ & 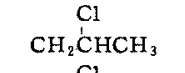 & $\mathrm{Cl}$ & 1 & 0 & 1 \\
\hline 3 & $3-\mathrm{Cl}$ & $\mathrm{H}$ & $\stackrel{\mathrm{Cl}}{\mathrm{Cl}}$ & $\mathrm{Cl}$ & 5 & 3 & 1 \\
\hline 4 & $4-\mathrm{Cl}$ & $\mathrm{H}$ & $\underset{\mathrm{Cl}}{\mathrm{Cl}}{ }_{\mathrm{CH}_{2} \mathrm{C}}^{\mathrm{C}}$ & $\mathrm{Cl}$ & 5 & 5 & 4 \\
\hline 5 & $2,4-\mathrm{di}-\mathrm{Cl}$ & $\mathrm{H}$ & $\mathrm{CH}_{2} \stackrel{\mathrm{Cl}}{\mathrm{Cl}} \mathrm{CHCH}_{3}$ & $\mathrm{Cl}$ & 0 & 0 & 0 \\
\hline 6 & $3,4-\mathrm{di}-\mathrm{Cl}$ & $\mathrm{H}$ & $\mathrm{CH}_{2} \stackrel{\mathrm{Cl}}{\mathrm{Cl}} \mathrm{HCH}_{3}$ & $\mathrm{Cl}$ & 0 & 0 & 0 \\
\hline 7 & $4-\mathrm{CH}_{3}$ & $\mathrm{H}$ & $\mathrm{CH}_{2} \mathrm{CHCH}_{3}$ & $\mathrm{Cl}$ & 0 & 0 & 0 \\
\hline 8 & $4-\mathrm{NO}_{2}$ & $\mathrm{H}$ & $\mathrm{CH}_{2} \mathrm{CHCH}_{3}$ & $\mathrm{Cl}$ & 5 & 5 & 3 \\
\hline 9 & $\begin{array}{l}\text { 2-OH, } \\
3,5-\mathrm{di}-\mathrm{Br}\end{array}$ & $\mathrm{H}$ & $\underset{\mathrm{Cl}}{\mathrm{Cl}}$ & $\mathrm{Cl}$ & 0 & 0 & 0 \\
\hline 10 & $3-F$ & $\mathrm{H}$ & $\begin{array}{c}\mathrm{Cl} \\
\mathrm{CH}_{2} \mathrm{CHCH}_{3} \\
\mathrm{Cl}\end{array}$ & $\mathrm{Cl}$ & 3 & 3 & 1 \\
\hline 11 & $4-F$ & $\mathrm{H}$ & $\begin{array}{c}\mathrm{Cl} \\
\mathrm{CH}_{2} \mathrm{CHCH}_{3}\end{array}$ & $\mathrm{Cl}$ & 3 & 3 & 1 \\
\hline 12 & - & $\mathrm{H}$ & $\mathrm{CH}_{2} \mathrm{CH}_{2} \mathrm{Cl}$ & $\mathrm{Cl}$ & 0 & 5 & 0 \\
\hline 13 & $4-\mathrm{Cl}$ & $\mathrm{H}$ & $\mathrm{CH}_{2} \mathrm{CH}_{2} \mathrm{Cl}$ & $\mathrm{Cl}$ & 2 & 3 & 0 \\
\hline 14 & $2-\mathrm{Cl}$ & $\mathrm{H}$ & $\mathrm{CH}_{2} \mathrm{CH}_{2} \mathrm{CH}_{2} \mathrm{Cl}$ & $\mathrm{Cl}$ & 0 & 0 & 0 \\
\hline 15 & $4-\mathrm{Cl}$ & $\mathrm{H}$ & $\mathrm{CH}_{2} \mathrm{CH}_{2} \mathrm{CH}_{2} \mathrm{Cl}$ & $\mathrm{Cl}$ & 0 & 0 & 0 \\
\hline 16 & $2-\mathrm{Cl}$ & $\mathrm{H}$ & $\begin{array}{c}\mathrm{Br} \\
\mathrm{CH}_{2}{ }_{\mathrm{Br}} \mathrm{CHCH}_{3}\end{array}$ & $\mathrm{Br}$ & 0 & 0 & 0 \\
\hline 17 & $4-\mathrm{Cl}$ & $\mathrm{H}$ & $\underset{\mathrm{CH}_{2} \mathrm{CHCH}_{3}}{\mathrm{Br}}$ & $\mathrm{Br}$ & 5 & 5 & 1 \\
\hline 18 & $3,4-\mathrm{di}-\mathrm{Cl}$ & $\mathrm{H}$ & 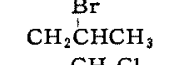 & $\mathrm{Br}$ & 0 & 0 & 0 \\
\hline 19 & $2-\mathrm{Cl}$ & $\mathrm{H}$ & $\mathrm{CH}_{\backslash}^{\prime} \mathrm{CH}_{2} \mathrm{CH}_{3}$ & $\mathrm{Cl}$ & 0 & 0 & 0 \\
\hline 20 & $4-\mathrm{Cl}$ & $\mathrm{H}$ & $\mathrm{CH}_{\triangle}^{\prime}{ }_{\mathrm{CH}} \mathrm{CH}_{2} \mathrm{CH}_{3}$ & $\mathrm{Cl}$ & 0 & 0 & 0 \\
\hline 21 & - & Ethyl & $\mathrm{CH}_{2} \mathrm{CH}_{2} \mathrm{Cl}$ & $\mathrm{Cl}$ & 0 & 0 & 0 \\
\hline 22 & $2-\mathrm{Cl}$ & Ethyl & $\mathrm{CH}_{2} \mathrm{CH}_{2} \mathrm{Cl}$ & $\mathrm{Cl}$ & 0 & 0 & 0 \\
\hline 23 & $3,4-\mathrm{di}-\mathrm{Cl}$ & Ethyl & $\mathrm{CH}_{2} \mathrm{CH}_{2} \mathrm{Cl}$ & $\mathrm{Cl}$ & 5 & 3 & 0 \\
\hline 24 & 4- $\mathrm{Cl}$ & Ethyl & $\mathrm{CH}_{2} \mathrm{CH}_{2} \mathrm{BT}$ & $\mathrm{Br}$ & 1 & 1 & 0 \\
\hline 25 & - & Methyl & $\mathrm{CH}_{2} \mathrm{CH}_{2} \mathrm{Cl}$ & $\mathrm{Cl}$ & 0 & 0 & 0 \\
\hline 26 & $2-\mathrm{Cl}$ & Methyl & $\mathrm{CH}_{2} \mathrm{CH}_{2} \mathrm{Cl}$ & $\mathrm{Cl}$ & 0 & 0 & 0 \\
\hline 27 & $4-\mathrm{Cl}$ & Methyl & $\mathrm{CH}_{2} \mathrm{CH}_{2} \mathrm{Cl}$ & $\mathrm{Cl}$ & 0 & 0 & 0 \\
\hline 28 & $4-\mathrm{Cl}$ & Methyl & $\mathrm{CH}_{2} \mathrm{CH}_{2} \mathrm{Br}$ & $\mathrm{Br}$ & 0 & 0 & 0 \\
\hline
\end{tabular}

注 1) 老中 $\mathrm{X}, \mathrm{R}_{1}, \mathrm{R}_{2}, \mathrm{Y}$ は $\mathrm{CH}_{2} \cdot \mathrm{N}_{\mathrm{R}_{2}}^{\prime \mathrm{R}_{1}} \cdot \mathrm{HY}$ 厄ある.

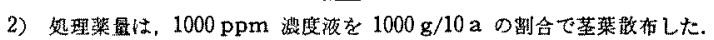

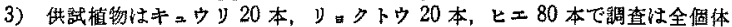
について行なった.

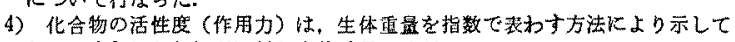

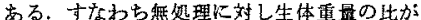

0 20\%の場合 5 21 40\%の場合 4 41 60\%の埸合 3

61 80\%の場合 2 81 95\%の場合 1 95 100\%の場合0となっている.

5) * 刘照菜成. PCP-Na (sodium pentachlorophenoxide), ATA (3-amino-1, 2, 4-triazole)
活性は全く認められなかった。

\section{Nーアルキルーベンジルアミン誘導体の化} 学構造上植物生理活性

前述のNーハロアルキルーペンジルアミン誘導 体の $\mathrm{R}_{2}$ はハロプロピル基拉よびハロエチル基 であったが，n-プロピル基，イソプロピル基， nーブチル基，イソブチル基，tert-ブチル基拉上 びアリル基を置換した場合に括ける植物生理活 珄の变化を確かめ，その結果を第 2 表に示し た。

第 2 表 Nーアルキルーベンジルアミン誘導 体の化学棈造と植物生理活性

\begin{tabular}{|c|c|c|c|c|c|}
\hline \multirow{2}{*}{$\begin{array}{l}\text { 番 } \\
\text { 号 }\end{array}$} & \multirow[b]{2}{*}{$X$} & \multirow[b]{2}{*}{$\mathrm{R}$} & \multicolumn{3}{|c|}{ 活性度（指数） } \\
\hline & & & $\begin{array}{l}\neq= \\
\emptyset 11\end{array}$ & 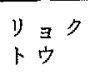 & $t=$ \\
\hline$*$ & $\mathrm{PCP}-\mathrm{Na}$ & - & 5 & 5 & 4 \\
\hline * & ATA & - & 5 & 5 & 4 \\
\hline 29 & - & $n$-propyl & 0 & 0 & 0 \\
\hline 30 & - & isopropyl & 0 & 0 & 0 \\
\hline 31 & $4-\mathrm{Cl}$ & isopropyl & 0 & 0 & 0 \\
\hline 32 & - & $n$-butyl & 0 & 0 & 0 \\
\hline 33 & $2-\mathrm{Cl}$ & $n$-butyl & 0 & 0 & 0 \\
\hline 34 & $4-\mathrm{Cl}$ & $n$-butyl & 0 & 0 & 0 \\
\hline 35 & $3,4-\mathrm{di}-\mathrm{Cl}$ & $n$-butyl & 0 & 0 & 0 \\
\hline 36 & $2-\mathrm{Cl}$ & tert-butyl & 5 & 0 & 0 \\
\hline 37 & $4-\mathrm{Cl}$ & tert-butyl & 0 & 0 & 0 \\
\hline 38 & - & isobutyl & 0 & 0 & 0 \\
\hline 39 & - & allyl & 0 & 0 & 0 \\
\hline 40 & $2-\mathrm{Cl}$ & allyl & 0 & 0 & 0 \\
\hline 41 & $4-\mathrm{Cl}$ & allyl & 0 & 0 & 0 \\
\hline
\end{tabular}

这 1) 溒中 $\mathrm{X}, \mathrm{R}$ 仕

2) * 対照薬剂

3）その他怡第1 唕と同し.

第 2 表の結果から，Nーアルキルーヘンシジルア ミン誘導体の場合は，供試化合物の5ちXが2クロ口基, $\mathrm{R}$ が tert-ブチル基のときキュウリ のみに強い活性が認められたほかは全く活㨫を 認めなかった。

3. N-フェノキシアルキル-2-ハロゲノプロ ピルアミン誘泪体の化学構造と植物生理 活性

植物ホルモンとして強力な活性を示す 2,4ジクロルフェノキシ系のうら $\mathrm{Cl}_{2} \mathrm{C}_{6} \mathrm{H}_{3} \mathrm{O}\left(\mathrm{CH}_{2}\right)_{n}$ $\mathrm{CONH}_{2}$ のごときはnの数によって活性あるい 
は不活性となり， すべてに活性が認められている，さらにフェノキシ酶酸 のベンゼン核への置换基の位置は，その活性の重要な要 素の1つであるといわれている(6).これらの事実から，

第3表 Nーフェノキシーアルキルー2-ハロゲノプロ ピルアミン誘導体の化学構造と植物生理活性

\begin{tabular}{|c|c|c|c|c|c|}
\hline \multirow{2}{*}{$\begin{array}{l}\text { 番 } \\
\text { 号 }\end{array}$} & \multirow[b]{2}{*}{$\mathrm{X}$} & \multirow[b]{2}{*}{$n$} & \multicolumn{3}{|c|}{ 活性度（指数） } \\
\hline & & & 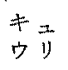 & $\begin{array}{l}\text { リ } \\
\text { ト }{ }^{\circ}\end{array}$ & $ヒ=$ \\
\hline * & $2,4-D$ & - & 5 & 5 & 3 \\
\hline$*$ & ATA & - & 5 & 5 & 4 \\
\hline 42 & $2-\mathrm{Cl}$ & 2 & 0 & 0 & 0 \\
\hline 43 & $3-\mathrm{Cl}$ & 2 & 5 & 5 & 1 \\
\hline 44 & $4-\mathrm{Cl}$ & 2 & 5 & 5 & 3 \\
\hline 45 & 2,4-di-Cl & 2 & 5 & 5 & 2 \\
\hline 46 & 2,6-di-Cl & 2 & 1 & 0 & 1 \\
\hline 47 & $2,4,5$-tri- $\mathrm{Cl}$ & 2 & 5 & 5 & 2 \\
\hline 48 & $2,4,6$-tri- $\mathrm{Cl}$ & 2 & 3 & 1 & 0 \\
\hline 49 & $2,3,4,6$-tetra-Cl & 2 & 4 & 2 & 2 \\
\hline 50 & $2,3,4,5,6$-penta-Cl & 2 & 3 & 2 & 2 \\
\hline 51 & - & 2 & 5 & 5 & 2 \\
\hline 52 & $2-\mathrm{CH}_{3}$ & 2 & 1 & 1 & 0 \\
\hline 53 & $3-\mathrm{CH}_{3}$ & 2 & 1 & 0 & 0 \\
\hline 54 & $4-\mathrm{CH}_{3}$ & 2 & 5 & 5 & 1 \\
\hline 55 & 2,4 -di- $\mathrm{CH}_{3}$ & 2 & 4 & 2 & 2 \\
\hline 56 & 3,5-di- $\mathrm{CH}_{3}$ & 2 & 0 & 0 & 0 \\
\hline 57 & $3,4-\mathrm{di}-\mathrm{CH}_{3}$ & 2 & 0 & 0 & 0 \\
\hline 58 & $3-\mathrm{CH}_{3}, 4-\mathrm{Cl}$ & 2 & 3 & 0 & 1 \\
\hline 59 & $2,4-\mathrm{di}-\mathrm{Cl}, 6-\mathrm{CH}_{3}$ & 2 & 3 & 0 & 1 \\
\hline 60 & $2-\mathrm{Br}$ & 2 & 1 & 0 & 0 \\
\hline 61 & $3-\mathrm{Br}$ & 2 & 5 & 5 & 2 \\
\hline 62 & $4-\mathrm{Br}$ & 2 & 5 & 5 & 3 \\
\hline 63 & $2-\mathrm{OCH}_{3}$ & 2 & 2 & 1 & 1 \\
\hline 64 & $4-\mathrm{OCH}_{3}$ & 2 & 4 & 2 & 1 \\
\hline 65 & $3-\mathrm{Cl}$ & 3 & 5 & 5 & 1 \\
\hline 66 & $4-\mathrm{Cl}$ & 3 & 5 & 5 & 2 \\
\hline 67 & $2-\mathrm{Cl}$ & 4 & 0 & 0 & 0 \\
\hline 68 & 4- $\mathrm{Cl}$ & 4 & 5 & 5 & 4 \\
\hline 69 & $4-\mathrm{Cl}$ & 5 & 5 & 5 & 3 \\
\hline 70 & 4-Cl & 6 & 5 & 5 & 3 \\
\hline 71 & $4-\mathrm{Cl}$ & 10 & 5 & 5 & 2 \\
\hline 72 & $4-\mathrm{I}$ & 2 & 5 & 5 & 3 \\
\hline 73 & $2-\mathrm{NO}_{2}$ & 3 & 1 & 1 & 0 \\
\hline 74 & $4-\mathrm{NO}_{2}$ & 3 & 1 & 5 & 0 \\
\hline 75 & $4-\mathrm{Br}$ & $\begin{array}{l}\quad 2, \\
\mathrm{Br}^{\mathrm{C}} \mathrm{CHCH}_{3} \cdot \mathrm{HBr}^{2}\end{array}$ & 5 & 5 & 4 \\
\hline
\end{tabular}

注 1) 淁中 $\mathrm{X}, n$ 忙<smiles>[Y]c1ccc(OCCNCC(Cl)CC(C)Cl)cc1</smiles>

2) * 娰照蔡剂, 2,4-D(2,4-dichlorophenoxyacetic acid) 3）去の他江第1 1 装と同じ。
筆者らは合成したNーフェノキシアルキルー2-ハロゲノブ ロピルアミン誘導体について，化学構造と生理活性との 関係を検討した。艺の結果は第3表に示してある。

第 3 表の結果から明らかなよ 5 に、Nーフェノキシフ ルキルー2-ハロダノプロピルアミン誘導体では，活性の ある一連の化合物を見出した，このときに拈ける活性作 用はフェノキシ酢酸系化合物とは全く異なり，特徴ある クロ シシス作用を示した。すなるわ，1）Xが1個で $n=$ 2 の場合は，Xが4位置換で最も活性が強く，その順位 はクロロ=ブロム基〉メキル基〉メトキシ基であった。 ついで活性の高いむのは3位にクロロまたはブロム基が 置換された場合であった，2位に置換基が入った場合は クロロ，ブロム，メチル，メトキシのいすれの置换基で あってもその活性は著しく低下した，2) Xが2 個以上 で $n=2$ の場合はXがクロ口もしくはメチル基で 2,4 位 に置換したときには 1) についで活性が高かった。この 際ク口口基の場合は 2,4 位のほかに 3 位，6位にもクロ 口基がさらに入ると活性は低下した。なお施がィ基 で 3,4 位执よび 3,5 位置換では全く活性を認めなかっ た. 3）nの数を3以上にし，Xが 4-ク口ロ基の場合は $n=3$ 特よび 10 のを载培七工のみに対し活性が低下す る傾向を認めた４）さらに $n=2$ についてXがブロム基 で，側鎖の 2-クロロープロピルアミノ基を 2-ブロムープ ロピルアミノ基とし活性を調ベた結果では，匡とんど同 じ活性力価が認められた。

4. N-フェニルチオアルキル-2-ハロゲノプロピルア ミン誘等体の化学構造之植物生理活性

フェノキシ酰酸の側鎖の基部の酸素をイオウにしたチ オグリニール酸系化合物は, 環をクロロその他で置換す

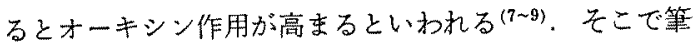
者らは，前記のフェノキシアルキル type の化合物 2,3

第 4 表 Nーフェニルチオフルキルー2-クロルプロビ ルアミン諉導体の植物生理活性

\begin{tabular}{|c|c|c|c|c|c|}
\hline \multirow{2}{*}{ 番号 } & \multirow{2}{*}{$\mathrm{X}$} & \multirow{2}{*}{$n$} & \multicolumn{3}{|c|}{ 活 性 度（指数） } \\
\hline & & & キュウリ & リョクトウ & k \\
\hline 76 & $4-\mathrm{Cl}$ & 3 & 5 & 5 & 2 \\
\hline 77 & - & 3 & 0 & 0 & 0 \\
\hline 78 & $4-\mathrm{Cl}$ & 3 & 0 & 0 & 0 \\
\hline 79 & $4-\mathrm{NO}_{2}$ & 3 & 5 & 4 & 2 \\
\hline
\end{tabular}

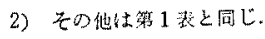


をさらにフェニルチォフルキル type としてその活性を 検討した，その結果については第 4 表に示した。

第 4 表の結果から明らかなように，フェニルチオアル キル typeでもXが 4 -ク口口基で $n=2$ の場合また はX が 4-ニト口基で $n=3$ のときにかなり活性が高い ことを諗めた。しかし，一般にフェノキシアルキル type の化合物に比べると，その活性はやや低い上うです。 た.

\section{5.その他の関運アミン化合物の植物生理活性}

以上の史験結果から，筆者らの合成したアミン誘導体 の作用性は，主として 2-ハロゲノプロピルアミノ基に 起因するものか，あるいはこれと環とが結合した䊒造で のみ活性を示すのかを检討するため第 5 表のごとき化合 物を合成しその活性を検討した。なお，あわせてNーフ

第 5 表 その他のアミン誘道体の植物生理活性

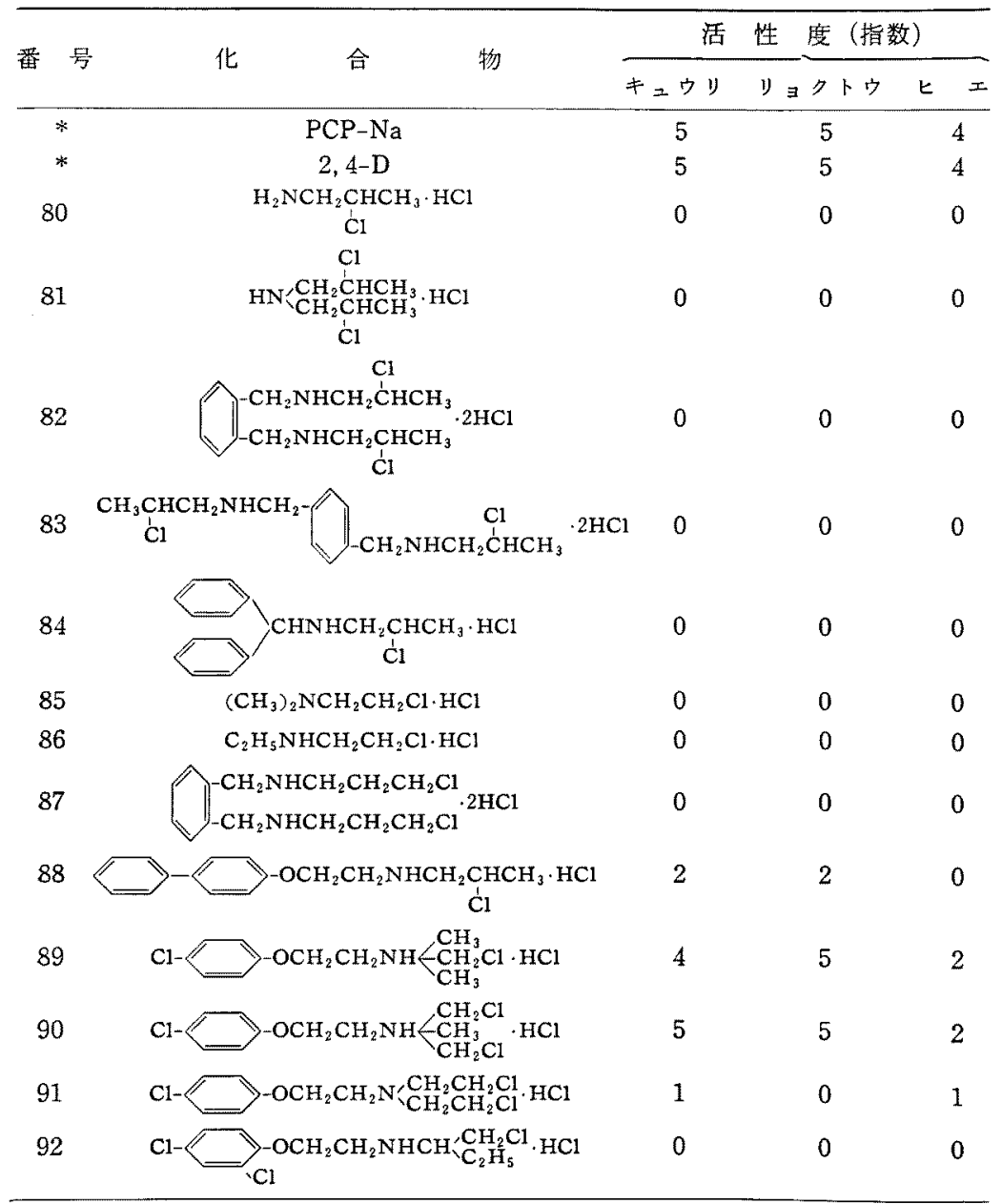

这)然駼条件は第 1 表と同 $\mathrm{L}$.
エノキシアルキルー2-ハロゲノプロピルアミン誘導体の 構造式中 2-ハロゲノプロピル基を変えた場合，如よび 2,3の関連化合物の活性について子检討した. その結果 は第 5 表に示した。

第 5 表の結果から明らかなよ5に，環が除かれれば活 性は全く消失した。また 2-ハ口ゲノプロピル基を 1,1一 ジメチルー2ークロロエチル基または 1,1-クロ中メチルエ チル基に変えた場合は，表に示したようにキュウリ，リ ョタトウに対してのみ强い活性を認めたが，ヒエについ ては2-ハロら゙ノプロピル基に比べて活性は低いよ5で あった，その他の化合物の活性は著しく低かった。

\section{6. 新了ミ之誘導体の植物生理活性の比較}

以上, $1 \sim 5$ にって得られたアミン誘導体の5ち, とくに活性が認められた化合物を選び，詳細にその活性 を比較するため，シャーレ内 でクロロシス発現の程度执よ びメヒシバ殺草力を調へた。 その結果は第 6 表に示した。

第 6 表の結果から，1） Nハロアルキルーヘンジルアミ ン誘導体では，クロロシス発 現作用においてXが 4 多口 口基の性 5 が4-二ト口基上 り強力であったが，メヒシバ 殺草力は卧同じであった。 2) Nーフェノキシアルキルー2 ーハロゲノプロピルアミン誘 導体では，nの数によって活 性が異なり，Xが4-ク口基 でnが2，5，6の場合，强い クロロシス作用と殺草力を示 し，その程度は供試化合物の 5ちでは最強であった. $n$ が $3,4,10$ の場合, クロロシス 作用は強いが殺草力は彁か。 た。 またが 4-ブロム基で $\mathrm{R}_{1}$ が水素, $\mathrm{R}_{2}$ が 2-ク口ロプ ロピル基あるいは2-ブロム プロピル基の樘合，クロロシ 不作用はX $\mathrm{X}$ が 4-クロ基见 比べて低いが，殺草力に批い ては同程度であった.3)さら 
第 6 表 植物生理活性の認められた新アミン誘導体の効力の比較

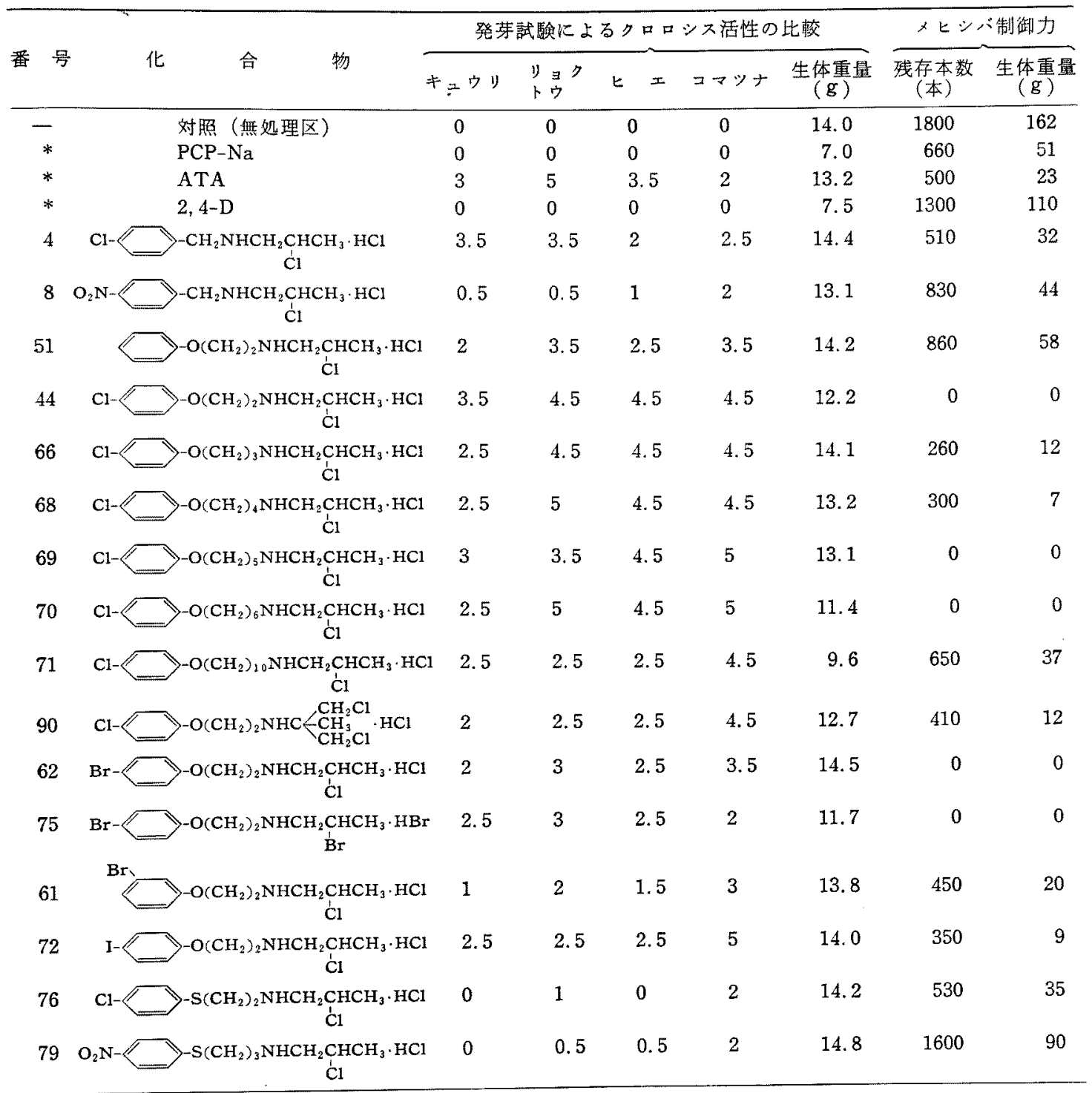

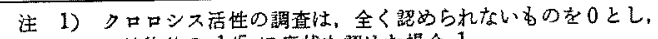

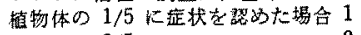

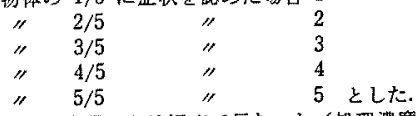

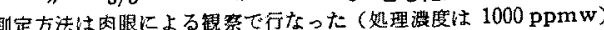

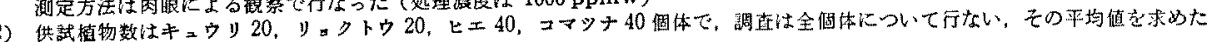

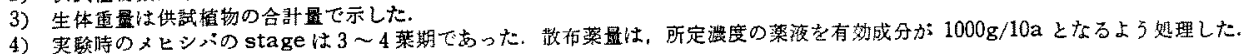

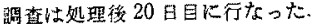

にNーフェニルチオアルキルー2-ハロダノプロピルアミン 誘導体ではクロロシス作用, メヒシバ殺草力ともにフェ ノキシアルキル type に比ベてかなり弱かったが, その 作用発現症状は全く同じであった。
7. 新アミン誘導体の魚毒性および紫外線に対する安 定性ならびに土壤中移動性 実駼結果は第 $7 \sim 9$ 表に示した。 まず魚毒性は第 7 表から明らかなように，対照薬郕の 


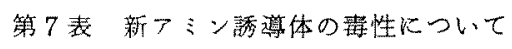

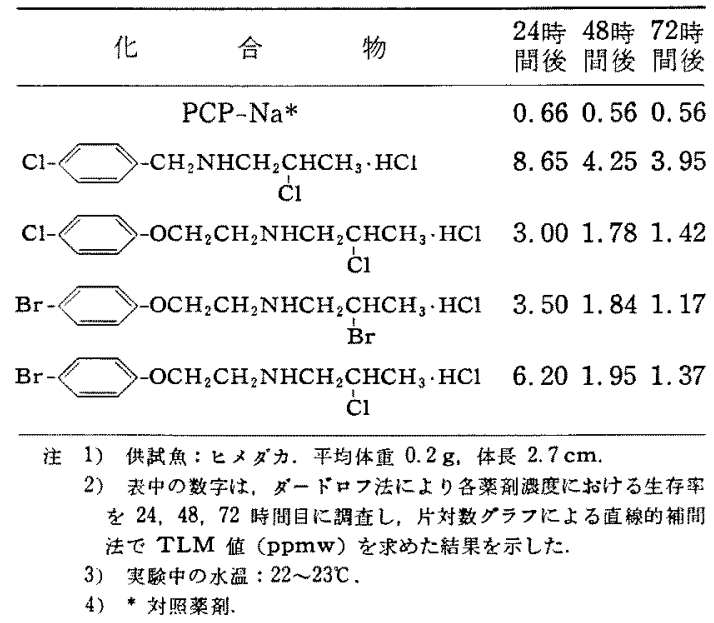

PCP-Naよりも低い，また紫外線に対する女定性も第 8 表の結果からきわめて高いようである。な和陽光下に祝 いても同程度の安定性を確認している (未発表).さら に土壤中での移動程度は第 9 表の結果加ら多て水田条件 下では対照薬剤の PCP-Na と同程度と判断される。

$$
\text { 考察 }
$$

新しいtype の植物生理活性を示すアミン誘尊体 $\mathrm{N}$ ハロアルキルーペンジルアミン誘導体，N-アルキルーへ

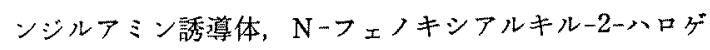
フプロピルアミン誘導体，およびN-フェニルチオアル キル-2-ハャゲノプロビルアミン誘導体について，その 化学構造と植物生理活性との関係を検討した，艺の結果，

（1）上記 4 種誘導体の5らN-アルキルーペンジルア ミン誘導体以外は，供試植物に対して特異的な生理活性

第 8 表紫外楾に対する安定性

\begin{tabular}{|c|c|c|c|c|c|c|c|c|c|c|c|c|c|c|c|c|}
\hline \multirow{4}{*}{$\begin{array}{c}\text { 渡 } \\
(\mathrm{ppmw})\end{array}$} & \multicolumn{8}{|c|}{ 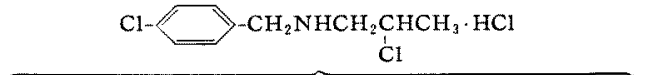 } & \multicolumn{8}{|c|}{$\mathrm{PCP}-\mathrm{Na} *$} \\
\hline & \multicolumn{2}{|c|}{ 無 } & \multicolumn{2}{|c|}{ 理 } & \multicolumn{4}{|c|}{ 柴外線 処理 } & \multicolumn{2}{|c|}{ 然 } & \multicolumn{2}{|c|}{ 迈 理 } & \multicolumn{4}{|c|}{ 紫外線拠理 } \\
\hline & \multirow{2}{*}{$\neq=$} & & \multicolumn{2}{|c|}{ リョクトウ } & \multirow{2}{*}{$\overbrace{(a)}^{\neq}$} & \multirow{2}{*}{$\frac{\dot{ }(b)}{(b)}$} & \multicolumn{2}{|c|}{ リョクトウ } & \multirow{2}{*}{$\frac{7}{(a)}$} & \multirow{2}{*}{$\frac{(b 1)}{(b)}$} & \multicolumn{2}{|c|}{ リ $\exists ク ト ウ$} & \multirow{2}{*}{\multicolumn{2}{|c|}{$\overbrace{(a)(b)}^{\neq(b)}$}} & \multicolumn{2}{|c|}{ リョクトウ } \\
\hline & & (b) & (a) & (b) & & & (a) & (b) & & & (a) & $(b)$ & & & (a) & (b) \\
\hline 0 & 100 & 1.3 & 100 & 3.6 & - & - & - & - & - & - & - & - & - & - & - & 一 \\
\hline 10 & 100 & 1.3 & 100 & 3.0 & 100 & 1.1 & 100 & 2.6 & 100 & 0.6 & 100 & 2.5 & 100 & 1.0 & 90 & 2.0 \\
\hline 25 & 100 & 1.0 & 100 & 3.6 & 100 & 0.8 & 100 & 2.5 & 90 & 0.3 & 60 & 1.2 & 100 & 0.9 & 100 & 2.7 \\
\hline 50 & 90 & 1.0 & 100 & 3.2 & 100 & 0.9 & 100 & 2.9 & 80 & 0.4 & 20 & 0.2 & 90 & 1.1 & 100 & 2.3 \\
\hline 100 & 100 & 1.1 & 90 & 2.4 & 100 & 1.1 & 100 & 2.8 & 0 & 0 & 0 & 0 & 100 & 1.0 & 100 & 2.9 \\
\hline 250 & 100 & 1.2 & 100 & 2.5 & 90 & 1.0 & 100 & 2.1 & 0 & 0 & 0 & 0 & 100 & 0.5 & 80 & 1.8 \\
\hline
\end{tabular}

第 9 表 新 $フ$ ミン誘㰾体の土壤中移動性

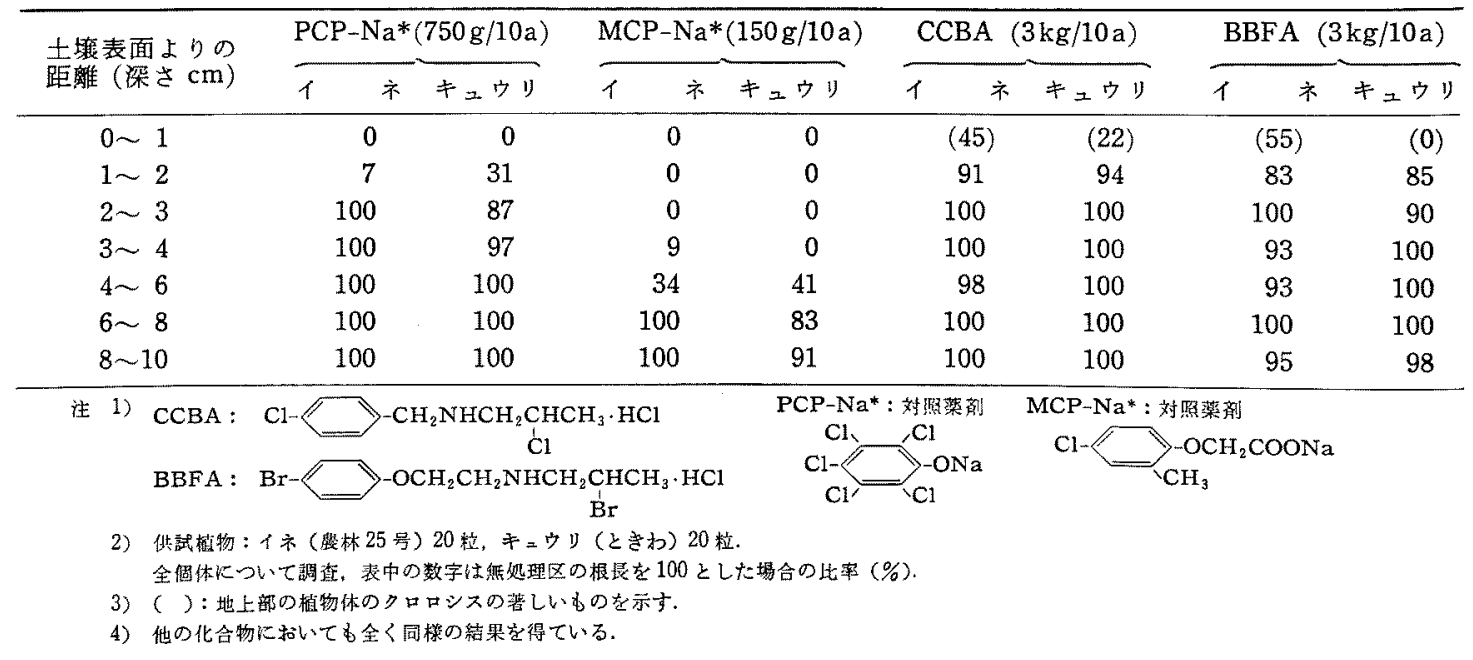


を示し，その特﨎は植物茥葉部のクロロシス作用である ことが判明した。

(2) 4 種誘導体の5ちNーアルキルーベンジルアミン 誘導体は他に比較して著しく活性が低いことから，強力 な生理活性を示すに不可欠な基団として，2-ハロゲノプ ロピルアミノ基が必要であることが推察される。

（3）環に直結する原子はＯ，S，Cいずれであっても 同じ症状の生理活性を示すが，その程度は $\mathrm{O}>\mathrm{C}>\mathrm{S}$ の 順位であった。

（4）環の置換基の条件は，本化合物が活性を示すた めには，1個または 2 個以上のハロゲン基，低級アルキ 儿基括よびニト口基などが必要で，その置換位置は4位 ハロダン原子置換が最強の活性を示した。しかし4位に 圈換基方方っても，さらに2，3，5，6 位に置換基が入 るとその活性は低下する，このことから，強力な活性を 示すためには 4 位以外に置換基がスってはいけないこと が推祭される。

（5）環に近接する $\left(-\mathrm{CH}_{2}-\right)_{n}$ は， N-フェノキシア ルキル-2-ハロゲノプロピルアミン誘導体について検討
を行なったが，環の 4 位がクロ口基に值換されたときn が 6 以内では活性に著しい差はないが，nが 3 たた 4 のときにやや劣る傾向があるほか，nが10ではさらに 低下するようである。

（6）第6表で示される本化合物特有のクロロシス化 作用は，2-ハロダノプロピルアミノ基と，八ロゲン＝ トロ，メチル基などが置換されたフェノキシ基，ベンジ ル基、フェニルチオ基との組合世に拈いてのみ発現する ものと判断される，その理由として第 5 表に示されてい るように，2-ハロゲノプロピルアミノ基のみでは本現象 は生じなかったほか，フェノキシ基，フェニルチ才基比 ついてとの誘導体には，植物生理活性としてクロロシ ス（白化）作用が認められていないからである。

（7）以上の結果加ら現在までに得られた最も強力な 活性のある化合物は $n=2,5,6$ でNーフェノキシアルキ ル-2-クロロプロピルアミン醏酸塩であり，魚瑇性低く， 土壤移動性も小さいことから害用化が可能であると考齐 られる

（8）今後は，生理作用の面からクロロシス発現機構 第 10 表 植物生理活性の認められたフミン化合物の融点执よび分析値

\begin{tabular}{|c|c|c|c|c|c|c|c|c|c|c|c|c|c|c|}
\hline \multirow{2}{*}{$\begin{array}{l}\text { 番 } \\
\text { 号 }\end{array}$} & \multirow{2}{*}{$\begin{array}{l}\text { 融点 } \\
\left({ }^{\circ} \mathrm{C}\right)\end{array}$} & 分 & 析 & 值 & \multirow{2}{*}{$\begin{array}{l}\text { 番 } \\
\text { 号 }\end{array}$} & \multirow{2}{*}{$\left({ }^{\circ}{ }^{\circ}{ }^{\circ} \mathrm{C}\right)$} & 分 & 析 & 值 & \multirow{2}{*}{$\begin{array}{l}\text { 番 } \\
\text { 奇 }\end{array}$} & \multirow{2}{*}{$\left({ }^{\circ}{ }^{\circ} \mathrm{C}\right)$} & \multicolumn{3}{|r|}{ 值 } \\
\hline & & $\mathrm{C}(\%)$ & $\mathrm{H}(\%)$ & $\mathrm{N}(\%)$ & & & $\mathrm{C}(\%)$ & $\mathrm{H}(\%)$ & $\mathrm{N}(\%)$ & & & $\mathrm{C}(\%)$ & $\mathrm{H}(\%)$ & $\mathrm{N}(\%)$ \\
\hline 2 & 140 & $\begin{array}{c}47.34 \\
(47.18)\end{array}$ & $\begin{array}{c}5.71 \\
(5.54)\end{array}$ & $\begin{array}{c}5.65 \\
(5.50)\end{array}$ & 49 & $207 \widetilde{208}$ & $\begin{array}{c}33.92 \\
(34.06)\end{array}$ & $\begin{array}{c}3.53 \\
(3.58)\end{array}$ & $\begin{array}{c}3.78 \\
(3.61)\end{array}$ & 65 & 170 & $\begin{array}{c}48.24 \\
(48.26)\end{array}$ & & $\begin{array}{c}4.60 \\
(4.69)\end{array}$ \\
\hline 3 & 190 & $\begin{array}{c}47.25 \\
(47.18)\end{array}$ & $\begin{array}{l}5.48 \\
(5.54)\end{array}$ & $\begin{array}{c}5.50 \\
(5.50)\end{array}$ & 50 & $217 \widetilde{218}$ & $\begin{array}{c}31.00 \\
(31.28)\end{array}$ & $\begin{array}{c}2.88 \\
(2.86)\end{array}$ & $\begin{array}{c}3.41 \\
(3.32)\end{array}$ & 66 & 199 & $\begin{array}{c}47.92 \\
(48.26)\end{array}$ & & \\
\hline 4 & $204 \sim 205$ & $\begin{array}{c}47.20 \\
(47.18)\end{array}$ & $\begin{array}{c}5.58 \\
(5.54)\end{array}$ & $\begin{array}{c}5.53 \\
(5.50)\end{array}$ & 51 & $\stackrel{175 \sim}{176}$ & $\begin{array}{c}52.85 \\
(52.81)\end{array}$ & $\begin{array}{c}6.81 \\
(6.85)\end{array}$ & $\begin{array}{c}5.57 \\
(5.60)\end{array}$ & 68 & 189 $\widetilde{190}$ & $\begin{array}{c}50.17 \\
(49.94)\end{array}$ & & \\
\hline 8 & $\underset{178}{176}$ & $\begin{array}{c}45.62 \\
(45.30)\end{array}$ & $\begin{array}{c}5.47 \\
(5.32)\end{array}$ & $\begin{array}{c}10.60 \\
(10.56)\end{array}$ & 52 & ${ }_{162}^{163}$ & & $\begin{array}{c}7.13 \\
(7.25)\end{array}$ & $\begin{array}{l}5.46 \\
(5.30)\end{array}$ & 69 & $\underset{191}{190 \sim ~}$ & $\begin{array}{c}51.50 \\
(51.47)\end{array}$ & & $\begin{array}{c}4.17 \\
(4.29)\end{array}$ \\
\hline 10 & ${ }_{191}^{190}$ & $\begin{array}{c}51.50 \\
(51.47)\end{array}$ & $\begin{array}{c}6.87 \\
(6.79)\end{array}$ & $\begin{array}{c}4.07 \\
(4.29)\end{array}$ & 53 & ${ }_{168}^{167}$ & $\begin{array}{c}54.79 \\
(54.56)\end{array}$ & $\begin{array}{c}7.38 \\
(7.25)\end{array}$ & $\begin{array}{l}5.40 \\
(5.30)\end{array}$ & 70 & ${ }_{177}^{178}$ & $\begin{array}{c}53.00 \\
(52.88)\end{array}$ & $\begin{array}{c}7.33 \\
(7.10)\end{array}$ & $\begin{array}{c}4.17 \\
(4.11)\end{array}$ \\
\hline 17 & $\stackrel{155 \sim}{157}$ & $\begin{array}{c}34.90 \\
(34.97)\end{array}$ & $\begin{array}{c}4.22 \\
(4.11)\end{array}$ & $\begin{array}{c}4.30 \\
(4.08)\end{array}$ & 54 & 191 & $\begin{array}{c}54.30 \\
(54.56)\end{array}$ & $\begin{array}{c}7.45 \\
(7.25)\end{array}$ & $\begin{array}{l}5.36 \\
(5.30)\end{array}$ & 71 & $\begin{array}{l}181 \sim \\
182\end{array}$ & $\begin{array}{c}57.60 \\
(57.51)\end{array}$ & & $\begin{array}{c}3.74 \\
(3.53)\end{array}$ \\
\hline 23 & 192 & $\begin{array}{c}43.59 \\
(43.63)\end{array}$ & $\begin{array}{c}4.95 \\
(4.99)\end{array}$ & $\begin{array}{c}4.97 \\
(4.62)\end{array}$ & 55 & ${ }_{170}^{169 \sim}$ & $\begin{array}{c}56.17 \\
(56.12)\end{array}$ & $\begin{array}{c}7.73 \\
(7.61)\end{array}$ & $\begin{array}{l}5.25 \\
(5.03)\end{array}$ & 72 & $\underset{196}{195 \sim}$ & $\begin{array}{c}35.05 \\
(35.13)\end{array}$ & $\begin{array}{c}4.14 \\
(4.29)\end{array}$ & $\begin{array}{c}3.79 \\
(3.72)\end{array}$ \\
\hline 36 & 253 254 & $\begin{array}{c}55.99 \\
(56.42)\end{array}$ & $\begin{array}{c}7.40 \\
(7.32)\end{array}$ & $\begin{array}{c}5.89 \\
(5.98)\end{array}$ & 58 & $\stackrel{186 \sim}{187}$ & $\begin{array}{c}48.61 \\
(48.26)\end{array}$ & $\begin{array}{c}5.95 \\
(6.08)\end{array}$ & $\begin{array}{c}4.87 \\
(4.69)\end{array}$ & 73 & $\begin{array}{l}209 \sim \\
210\end{array}$ & $\begin{array}{c}46.90 \\
(46.62)\end{array}$ & $\begin{array}{c}6.00 \\
(5.87)\end{array}$ & $\begin{array}{c}9.01 \\
(9.06)\end{array}$ \\
\hline 43 & 164 & $\begin{array}{c}46.60 \\
(46.42)\end{array}$ & $\begin{array}{c}5.70 \\
(5.67)\end{array}$ & $\begin{array}{c}4.97 \\
(4.92)\end{array}$ & 59 & $174 \sim$ & $\begin{array}{c}43.04 \\
(43.27)\end{array}$ & $\begin{array}{c}4.89 \\
(5.14)\end{array}$ & $\begin{array}{c}4.32 \\
(4.21)\end{array}$ & & 197 $\sim 198$ & $\begin{array}{c}46.59 \\
(46.62)\end{array}$ & $\begin{array}{c}5.93 \\
(5.87)\end{array}$ & $\begin{array}{c}9.25 \\
(9.06)\end{array}$ \\
\hline 44 & 185 & $\begin{array}{c}46.17 \\
(46.42)\end{array}$ & $\begin{array}{l}5.46 \\
(5.67)\end{array}$ & $\begin{array}{c}4.95 \\
(4.92)\end{array}$ & 60 & $\underset{139}{138 \sim}$ & $\begin{array}{c}40.07 \\
(40.15)\end{array}$ & $\begin{array}{c}4.91 \\
(4.90)\end{array}$ & $\begin{array}{c}4.35 \\
(4.26)\end{array}$ & 76 & $\stackrel{170 \sim}{171}$ & $\begin{array}{c}44.02 \\
(43.94)\end{array}$ & $\begin{array}{c}5.43 \\
(5.36)\end{array}$ & $\begin{array}{c}4.71 \\
(4.66)\end{array}$ \\
\hline 45 & 157 & $\begin{array}{c}41.38 \\
(41.41)\end{array}$ & $\begin{array}{c}4.79 \\
(4.74)\end{array}$ & $\begin{array}{c}4.33 \\
(4.39)\end{array}$ & 61 & $170 \sim$ & $\begin{array}{c}40.26 \\
(40.15)\end{array}$ & $\begin{array}{c}4.88 \\
(4.90)\end{array}$ & $\begin{array}{c}4.29 \\
(4.26)\end{array}$ & 79 & & $\begin{array}{c}44.19 \\
(44.31)\end{array}$ & $\begin{array}{c}5.60 \\
(5.58)\end{array}$ & $\begin{array}{c}8.67 \\
(8.61)\end{array}$ \\
\hline 46 & ${ }_{171} \sim$ & $\begin{array}{c}41.22 \\
(41.41)\end{array}$ & $\begin{array}{c}4.79 \\
(4.74)\end{array}$ & $\begin{array}{c}4.46 \\
(4.39)\end{array}$ & 62 & $\underset{174}{173}$ & $\begin{array}{c}40.19 \\
(40.15)\end{array}$ & $\begin{array}{c}4.84 \\
(4.90)\end{array}$ & $\begin{array}{c}4.41 \\
(4.26)\end{array}$ & 80 & ${ }_{138}^{137}$ & $\begin{array}{c}48.49 \\
(48.26)\end{array}$ & $\begin{array}{c}6.11 \\
(6.08)\end{array}$ & $\begin{array}{c}4.81 \\
(4.69)\end{array}$ \\
\hline 47 & $171 \sim$ & $\begin{array}{c}37.58 \\
(37.38)\end{array}$ & $\begin{array}{c}4.11 \\
\text { (3. } 99)\end{array}$ & $\begin{array}{c}4.12 \\
(3.96)\end{array}$ & 63 & ${ }_{162} \sim$ & $\begin{array}{c}51.22 \\
(51.44)\end{array}$ & $\begin{array}{c}6.53 \\
(6.83)\end{array}$ & $\begin{array}{c}5.04 \\
(5.00)\end{array}$ & 90 & $\underset{155}{154}$ & $\begin{array}{c}43.43 \\
(43.27)\end{array}$ & $\begin{array}{l}5.26 \\
(5.14)\end{array}$ & $\begin{array}{c}4.25 \\
(4.20)\end{array}$ \\
\hline 48 & $\stackrel{190 \sim}{191}$ & $\begin{array}{c}37.38 \\
(37.38)\end{array}$ & $\begin{array}{c}4.00 \\
(3.99)\end{array}$ & $\begin{array}{c}4.06 \\
(3.96)\end{array}$ & 64 & $171 \widetilde{172}$ & $\begin{array}{c}51.67 \\
(51.44)\end{array}$ & $\begin{array}{c}6.87 \\
(6.83)\end{array}$ & $\begin{array}{c}5.22 \\
(5.00)\end{array}$ & 91 & 140 & $\begin{array}{c}43.34 \\
(43.27)\end{array}$ & $\begin{array}{c}5.29 \\
(5.14)\end{array}$ & $\begin{array}{c}4.31 \\
(4.20)\end{array}$ \\
\hline
\end{tabular}

注）分析値の（）内の数值は理論值を示す. 
についてその原因を究明し，さらに強力な活性のある化 合物を探究してみたい．

\section{要}

\section{約}

新アミン誘導体についてその植物生理活性を検討し た.その結果，

（1）クロロシス作用, 殺草作用ともに最も強力な化 合物はNーフェノキシアルキル-2-クロロプロピルアミン 誘導体であった。

（2）クロロシス作用の発現は環と2-ハロ ゙フプロ ピルアミノ基との組合せに乱いて最も強力であることが 判明した。

（3）環内の置換基は，4位ハロゲン基が他の置撸条 件に比較して高い活性を示した。

(4) 環に直結する原子と活性との関係は O>C >S の順位であった。

(5) $\left(-\mathrm{CH}_{2}\right)_{n}$ は $n=6$ 以内では $2,5,6$ の場合が 著しく強い活性を示した。

（6）魚毒性执よび土塆䔟動性ともにPCP-Naに比較 して小さく，柴外線に対してもきわめて安定であった，
終りに，本稿の御校閲の労を賜り衔助言をいただいた

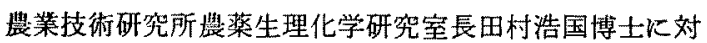
し厚く御礼申し上げる. またこの研究に当り終始ご指導 ご鞭婞を賜った当研究所所長秋葉朝一郎博士，生物研究 部長俈野簀博士，製品開発部長新田義博博士に対し厚く 御礼申し上げる。

本研究の大要は, 1968 年 10 月, 日本植物生理学会で 発表した。

(1) M. Nickerson : J. Pharmacol. Rev., 1,27(1949).

（2）荒井正堆，川島良一，片岡孝義：農及園， 33 (1), 59 (1958).

(3) P. Doudoroff, et al. : Sewage and Industria Wastes, 23 (11), 1380 (1951).

（4）秋定辰夫：農薬生産技術，10，35 (1964).

（5）荒井正雄，宮原益次，片间孝義：雑草研究，5, 90 (1966).

（6）田中正三：生化学講座，9，219 (1959).

(7) M. Sugii and A. Sugii : Bull. Inst. Chem. Res. Kyoto Univ., 31, 27 (1953).

(8) J.Kato: Mem. Coll. Sci. Univ. Kyoto, B., 21, 77 (1954).

(9) C. H. Fawcett, R. L. Wain and F. Wightman: Ann. Appl. Biol., 43, 342 (1955). 